\title{
Effect of Mobile Phone Radiation on Nodule Formation In the Leguminous Plants
}

\author{
SAPNA SHARMA and LEENA PARIHAR* \\ Department of Biotechnology and Biosciences, Lovely Professional University, \\ Jalandhar, Phagwara, Punjab (India) - 144411. \\ http://dx.doi.org/10.12944/CWE.9.1.21
}

(Received: February 01, 2014; Accepted: March 15, 2014)

\begin{abstract}
During the last decade, there has been a widespread increase in the usage of mobile phones which resulted in an increase in electromagnetic radiations in the environment. These radiations have harmful effect on both plants and human being. A study was conducted to explore the effects of these radiations on the plants. The radiation emitted from mobile phones show effect on the early growth and biochemical changes in the emerging seedlings of Pisum sativum (Pea) and Trigonella foenumgraecum (Fenugreek). It was observed that the radiations emitted from mobile phone show considerable increase in the germination percentage, seedling length, proteins, lipid and Guaiacol content in comparison to control seeds. Different exposure time treatments were taken for the study as $1 / 2$ hour, 1 hour, 2 hour, 4 hour and 8 hour. The biochemical parameter increases with increase in the radiation exposure. The study concluded that radiations emitted from mobile phone interfere with both morphological and the biochemical processes and affect the growth and nodule formation in the plants. The number of nodules developed both in Pisum sativum and Trigonella foenumgraecum increases with increase in the radiation exposure.
\end{abstract}

Key words: Mobile phone radiation, Irradiated seeds, Radiated seeds, Pea and Fenugreek.

\section{INTRODUCTION}

Cell phone technology is the most common telecommunication in India. Due to its advantages, cell phone technology has grown exponentially in the last some years. Currently there are about 50 Crore cell phone users and 4.4 lakh cell phone towers in India. Radiation emitted from cell phone give a harmful effect on both plants and animals. These are mainly of two types-thermal radiations and non-thermal radiations. Thermal radiations are similar to microwave-oven. Non-thermal radiations are not well known but it is assume that they have more harmful effect on plants and animal. Now-aday most of the population in the world use cell phone for communication. Cell phone emits the microwave radiation. A cell phone transmits 1-2 watt of power in the frequency range of $824-1780 \mathrm{MHz}$. A cell phone has a SAR i.e. specific absorption rate (Kumar 2010). Plants, animals and human need nitrogen for their growth and metabolism. Nitrogen is a part of nucleic acid and has a very important role. Plants are not able to use nitrogen as present in the atmosphere because of the Na"N. They use nitrogen in the form of nitrate. Legumes are the special plants which have ability to fix nitrogen because of their nature of symbiosis with Rhizobium bacteria (Lavoisier 2000). In bacteria bacteroids were responsible for the formation of nodule in the root (Beijerinck 1888). Now-a-days many towers are building in the field and many other places near the agricultural fields which affect the plants in all different aspects. The radiations effect may be positive or negative on the growth and development of plants. So to validate the hypothesis the current study presents about the effect of microwave radiation emitted from mobile phone on the leguminous plants i.e. Pea and Fenugreek. 


\section{$2 G$ and $3 G$ cell phone}

There are different types of cell phone technologies which are used today 1G, 2G, 3G, and $4 \mathrm{G}$. The most widely used cell phone technologies are $2 G$ and $3 G$. $2 G$ are the second generation wireless telephone. Three primary benefits of $2 \mathrm{G}$ networks are that the phone conversations are digitally encrypted. $2 \mathrm{G}$ systems are significantly more efficient on the spectrum allowing for far greater mobile phone penetration levels; and 2G introduced data services for mobile, starting with SMS text messages. The frequency range for $2 \mathrm{G}$ is 824 to $894 \mathrm{MHz}$ (Ashisho 2003). The $3 G$ phone are third generation wireless telephone. They are much advance than $2 G$ and the frequency range of 900 to 1900 which is higher than 2G. Radiation emitted from cell phone give a harmful effect on both plants and animals. It has been shown that the radiations emitted from mobile phone are carcinogenic for human being. Beside this they also have harmful effect on the plants (Smith et al. 2000). In this study the main aim was to check the in vitro and in vivo effect of $2 G$ and $3 G$ mobile phone radiations on Pea and Fenugreek.

\section{MATERIALS AND METHODS}

\section{Chemicals and instruments}

TCA (Tricarboxylic acid), TBA (Thiobarbutiric acid), Bovine serum albumin, Folin reagent, Folin and Ciocalteu's phenol reagent (2N), Sodium Tartrate, Copper Sulphate, $\mathrm{NaOH}, \mathrm{Na}_{2} \mathrm{CO}_{3}$, Sodium Phosphate buffer $(0.15 \mathrm{M})$, Hydrogen Peroxide (0.176 M), Guaiacol (0.1M). Centrifuge (REMI Instrument Ltd. Mumbai. India), Hot air oven (Microsil India), Autoclave (NSW. India Pvt. Ltd. New Delhi).

\section{Morphological analysis}

The seeds of Pea and Fenugreek were obtained from Punjab Agricultural University (PAU) Ludhiana with variety of Pea (PB-29) and Fenugreek (Kusturi methi) for experimental research work. Seeds were mainly splits into two groups- control and irradiated. Seeds of Pea and Fenugreek were soaked in DW for 8 hours. The seeds were then placed in air tight plastic boxes lined with filter paper moistened with DW. A Nokia 2690 mobile phone with frequency band 850- 1850 $\mathrm{MHz}$ was used to irradiate the seeds and same sample of seeds were taken as control without exposing towards radiations to compare the effect of radiations on Pea and Fenugreek. Different exposure time subjected to the seeds to check the effect of radiations like $1 / 2$ hour, 1 hour, 2 hours, 4 hours and 8 hours. After this the seeds were left for germination at least for 72 hours and then further tests are conducted to evaluate the effect of radiation on seedling and compare with the control. For finding the effect of variations in frequency, the other set of seeds was irradiated by the mobile phone having $3 G$ technologies. In this set seeds were irradiated through Samsung GT B7722 with frequency band $900-1900 \mathrm{MHz}$. For performing the experiment one set of seeds were exposed to radiations and other was taken as control in which no radiations were given as in $2 \mathrm{G}$. Similar procedures were followed for the biochemical investigation. One set of seeds exposed with $2 \mathrm{G}$ and $3 G$ mobile phone radiation was left for germination to evaluate the in vitro morphological parameters. After 72 hour of radiations exposure, morphological analysis was done by note down the number of seeds germinated, seedling length estimation through length of plumule and radical and fresh weight was recorded by weighing all the seeds. Seedlings after fresh weight allowed drying at $70^{\circ} \mathrm{C}$ for $24 \mathrm{~h}$ to record the dry weight. After this the relative water content (R.W.C.) of seeds is recorded by the formula- Fresh weight-Dry weight/ Fresh weight ${ }^{*} 100$. For in vivo evaluation the soil was obtained from the field of Fenugreek and Pea respectively as the nitrogen fixing bacteria (Rhizobium) is naturally present in the soil. Rhizobium is the bacteria which show the symbiotic association with root system of leguminous plants and help to fix the nitrogen and provide the same to plant for all nitrogen based metabolic activities. After radiation exposure one set of control and irradiated seeds were sown in the pots and left them for minimum 45 days as this period is sufficient for nodule formation in the plant. The pots were watered daily for proper growth and development.

\section{Biochemical Analysis}

In the biochemical analysis different test has been performed which include Protein estimation test, Lipid peroxidase test and Guaiacol peroxidase test. 


\section{Lipid Peroxidation Test}

Homogenization of $0.2 \mathrm{~g}$ of seedlings was performed by addition of $1 \mathrm{ml}$ of $5 \%$ TCA solution using pestle and mortar. Centrifugation of the homogenate was done at $12000 \mathrm{rpm}$ for $15 \mathrm{~min}$. at room temperature. To the $1 \mathrm{ml}$ of supernatant addition of $4 \mathrm{ml}$ of $0.5 \%$ TBA in $20 \%$ TCA Solution was done and after that the sample was incubated at $96^{\circ} \mathrm{C}$ for $30 \mathrm{~min}$. immediately the test tubes were kept in ice bath and then centrifuged at $2000 \mathrm{rpm}$ for $10 \mathrm{~min}$. The absorbance was recorded at 600 $\mathrm{nm}$ (Afzal and Mansoor 2012).

\section{Protein Estimation}

$0.5 \mathrm{ml}$ of supernatant was transferred to a glass tube and addition of $0.7 \mathrm{ml}$ Lowry solution was done. After this the tubes were covered and incubated for $20 \mathrm{~min}$. In the last five minutes Folin reagent was prepared. After 20 min of incubation the samples were taken out and addition of $0.1 \mathrm{ml}$ of diluted Folin reagent was done. Incubation was done once again for 30 minutes or longer at room temperature. After 30 minutes the sample was transferred into cuvette and optical density was taken at 750nm. Absorbance of this mixture was recorded against the BSA (Lowry et.al 1951).

\section{Guaiacol Peroxidation}

The seeds sample was crushed and 50 $\mu \mathrm{L}$ of sample was taken in a test tube. To the sample addition of sodium phosphate buffer, Hydrogen peroxide and Guaiacol was done. Then incubation of the reaction mixture was done for 8 minutes. The absorbance was recorded at $470 \mathrm{~nm}$ (Afzal and Mansoor 2012).

\section{Statistical analysis}

Experiment was conducted with three replicates of each sample as $R_{1 P}, R_{2 P}, R_{3 P}$ for Pea seedling and $R_{1 F}, R_{2 F}, R_{3 F}$ for Fenugreek seedlings. Analysis of variance for morphological and biochemical parameters were performed by Standard Deviation Calculator.

Table 1: Standard error analysis of Pea seedling exposed with $2 \mathrm{G}$ mobile phone radiations

\begin{tabular}{lccccc}
\hline $\begin{array}{l}\text { Time of } \\
\text { exposure }\end{array}$ & $\begin{array}{c}\text { Germination } \\
(\%)\end{array}$ & $\begin{array}{c}\text { Seeding } \\
\text { length( } \mathbf{c m})\end{array}$ & $\begin{array}{c}\text { FW } \\
(\mathbf{g m})\end{array}$ & $\begin{array}{c}\text { DW } \\
\mathbf{( g m})\end{array}$ & $\begin{array}{c}\text { R.W.C. } \\
(\%)\end{array}$ \\
\hline Control & $86.66 \pm 5.77$ & $2.64 \pm 0.33$ & $6.43 \pm 0.10$ & $1.80 \pm 0.05$ & $71.9 \pm 1.30$ \\
1/2 hour & $73.33 \pm 11.54$ & $2.77 \pm 0.32$ & $6.43 \pm 0.08$ & $1.86 \pm 0.02$ & $70.0 \pm 71.06$ \\
1 hour & $93.33 \pm 5.77 \mathrm{~ns}$ & $2.95 \pm 0.38$ & $6.84 \pm 0.57$ & $2.06 \pm 0.04$ & $69.6 \pm 2.46$ \\
2 hour & $93.33 \pm 5.77 \mathrm{~ns}$ & $2.93 \pm 0.32$ & $6.59 \pm 0.17$ & $2.12 \pm 0.08$ & $67.8 \pm 2.24$ \\
4 hour & $90.00 \pm 10$ & $3.03 \pm 0.27$ & $6.65 \pm 0.23$ & $2.48 \pm 0.45$ & $62.6 \pm 6.38$ \\
8 hour & $93.33 \pm 5.77 \mathrm{~ns}$ & $3.07 \pm 0.30$ & $6.73 \pm 0.30$ & $2.51 \pm 0.29$ & $62.7 \pm 5.62$ \\
\hline
\end{tabular}

F.W. = Fresh Weight, D.W. = Dry Weight, R.W.C = Relative Water Content, ns=designate Non- significant values

Table 2: Standard error analysis of Pea seedling exposed with 3 G mobile phone radiations

\begin{tabular}{|c|c|c|c|c|c|}
\hline $\begin{array}{l}\text { Time of } \\
\text { exposure }\end{array}$ & $\begin{array}{c}\text { Germination } \\
(\%)\end{array}$ & $\begin{array}{c}\text { Seeding } \\
\text { length }(\mathbf{c m})\end{array}$ & $\begin{array}{l}\text { FW } \\
(\mathrm{gm})\end{array}$ & $\begin{array}{l}\text { DW } \\
(\mathrm{gm})\end{array}$ & $\begin{array}{c}\text { R.W.C. } \\
(\%)\end{array}$ \\
\hline Control & $83.33 \pm 5.77 n s$ & $16.33 \pm 2.08$ & $6.35 \pm 0.09$ & $1.77 \pm 0.66$ & $72.06 \pm 1.28$ \\
\hline $1 / 2$ hour & $86.66 \pm 11.54 \mathrm{~ns}$ & $19.33 \pm 1.54$ & $6.03 \pm 0.37$ & $1.81 \pm 0.03$ & $69.84 \pm 1.84$ \\
\hline 1 hour & $93.33 \pm 5.77$ & $21.66 \pm 2.30$ & $6.14 \pm 0.09$ & $1.80 \pm 0.04$ & $70.45 \pm 0.72$ \\
\hline 2 hour & $83.33 \pm 5.77 n s$ & $19.76 \pm 5.40$ & $5.75 \pm 0.34$ & $1.97 \pm 0.04$ & $65.81 \pm 1.06$ \\
\hline 4 hour & $86.66 \pm 11.54 \mathrm{~ns}$ & $22.93 \pm 4.40$ & $5.80 \pm 0.22$ & $2.00 \pm 0.11$ & $65.44 \pm 0.88$ \\
\hline 8 hour & $83.33 \pm 15.27$ & $22.30 \pm 5.62$ & $5.65 \pm 0.26$ & $2.05 \pm 0.05$ & $63.55 \pm 1.43$ \\
\hline
\end{tabular}

F.W. = Fresh Weight, D.W. $=$ Dry Weight, R.W.C $=$ Relative Water Content, ns=designate Non- significant values 


\section{RESULT}

In morphological analysis of Pea seedling the replicates of control show variation with irradiated samples. The germination \%age of control is less than $8 \mathrm{hr}$ radiated seedlings. The exposure for short time does not show more effect on the seedling. As the exposure time increases the germination percentage also increases. The seed length, Fresh weight and dry weight also show an increase with increase in exposure time period

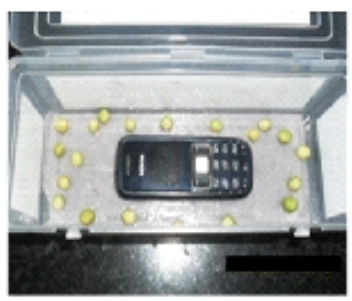

Pea Seeds with $2 \mathrm{G}$ exposure

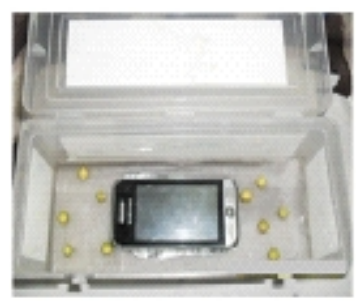

Pea Seeds with $3 G$ exposure

whereas RWC decreases with increase in radiation exposure in $2 \mathrm{G}$ exposed seeds. In $3 \mathrm{G}$ exposed seedling the fresh weight decrease while all other parameters increase.

In case of Fenugreek after 2G exposures the germination percentage, seed length and dry weight increase with increase in time period whereas the fresh weight and RWC decrease with increase in time period.

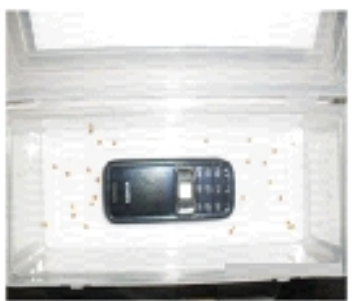

Fenugreek Seeds with $2 G$ exposure

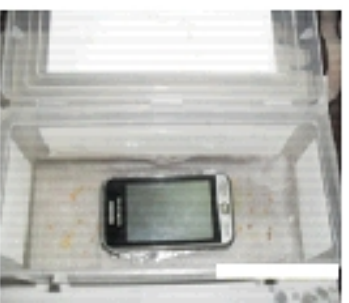

Fenugreek Seeds with $3 G$ exposure

Fig.1: Pea and Fenugreek Seeds with radiation exposure

Table 3: Standard error analysis of Fenugreek seedling exposed with 2G mobile phone radiations

\begin{tabular}{lccccc}
\hline $\begin{array}{l}\text { Time of } \\
\text { exposure }\end{array}$ & $\begin{array}{c}\text { Germination } \\
(\%)\end{array}$ & $\begin{array}{c}\text { Seeding } \\
\text { length }(\mathbf{c m})\end{array}$ & $\begin{array}{c}\text { FW } \\
(\mathbf{g m})\end{array}$ & $\begin{array}{c}\text { DW } \\
(\mathbf{g m})\end{array}$ & $\begin{array}{c}\text { R.W.C. } \\
(\%)\end{array}$ \\
\hline Control & $93.33 \pm 5.77 \mathrm{~ns}$ & $2.83 \pm 0.05$ & $0.13 \pm 0.01$ & $0.01 \pm 0.005$ & $89.49 \pm 5.34$ \\
$1 / 2$ hour & $96.66 \pm 5.77$ & $2.76 \pm 0.32$ & $0.12 \pm 0.01 \mathrm{~ns}$ & $0.02 \pm 0.015$ & $80.90 \pm 11.24$ \\
1 hour & $100 \mathrm{~ns}$ & $2.93 \pm 0.28$ & $0.12 \pm 0.01 \mathrm{~ns}$ & $0.02 \pm 0.010$ & $80.64 \pm 10.30$ \\
2 hour & $93.33 \pm 5.77 \mathrm{~ns}$ & $3.10 \pm 0.20$ & $0.15 \pm 0.03$ & $0.02 \pm 0.011$ & $75.29 \pm 17.10$ \\
4 hour & $100 \mathrm{~ns}$ & $3.60 \pm 0.34$ & $0.13 \pm 0.02$ & $0.01 \pm 0.011$ & $86.30 \pm 11.76$ \\
8 hour & $100 \mathrm{~ns}$ & $3.66 \pm 0.32$ & $0.11 \pm 0.02$ & $0.03 \pm 0.010$ & $71.72 \pm 14.80$ \\
\hline
\end{tabular}

F.W. = Fresh Weight, D.W. = Dry Weight, R.W.C $=$ Relative Water Content, ns=designate Non- significant values

Table 4: Standard error analysis of Fenugreek seedling exposed with 3G mobile phone radiations

\begin{tabular}{lccccc}
\hline $\begin{array}{l}\text { Time of } \\
\text { exposure }\end{array}$ & $\begin{array}{c}\text { Germination } \\
(\%)\end{array}$ & $\begin{array}{c}\text { Seeding } \\
\text { length( } \mathbf{~ c m})\end{array}$ & $\begin{array}{c}\text { FW } \\
(\mathbf{g m})\end{array}$ & $\begin{array}{c}\text { DW } \\
(\mathbf{g m})\end{array}$ & $\begin{array}{c}\text { R.W.C. } \\
(\%)\end{array}$ \\
\hline Control & $100 \mathrm{~ns}$ & $3.60 \pm 0.52$ & $0.13 \pm 0.02$ & $0.01 \pm 0.005 \mathrm{~ns}$ & $89.61 \pm 4.50$ \\
$1 / 2$ hour & $96.66 \pm 5.77 \mathrm{~ns}$ & $2.93 \pm 0.94$ & $0.13 \pm 0.01$ & $0.01 \pm 0.005 \mathrm{~ns}$ & $87.32 \pm 3.79$ \\
1 hour & $96.66 \pm 5.77 \mathrm{~ns}$ & $3.86 \pm 0.57$ & $0.13 \pm 0.04$ & $0.02 \pm 0.010$ & $82.93 \pm 9.68$ \\
2 hour & $100 \mathrm{~ns}$ & $3.63 \pm 0.37$ & $0.12 \pm 0.03$ & $0.02 \pm 0.003$ & $76.97 \pm 19.44$ \\
4 hour & $96.66 \pm 5.77 \mathrm{~ns}$ & $3.70 \pm 0.20$ & $0.10 \pm 0.03$ & $0.03 \pm 0.017$ & $75.79 \pm 9.54$ \\
8 hour & $100 \mathrm{~ns}$ & $3.86 \pm 0.15$ & $0.08 \pm 0.03$ & $0.02 \pm 0.005$ & $71.66 \pm 5.13$ \\
\hline
\end{tabular}

F.W. = Fresh Weight, D.W. = Dry Weight, R.W.C = Relative Water Content, ns=designate Non- significant values 
In the biochemical analysis also three replicates considered which are taken as mean value for one sample and designated as $R_{1 \mathrm{P}}, R_{2 \mathrm{P}}$, $R_{3 P}$ for Pea and $R_{1 F}, R_{2 F}, R_{3 F}$ for fenugreek. The biochemical analysis includes estimation of protein,

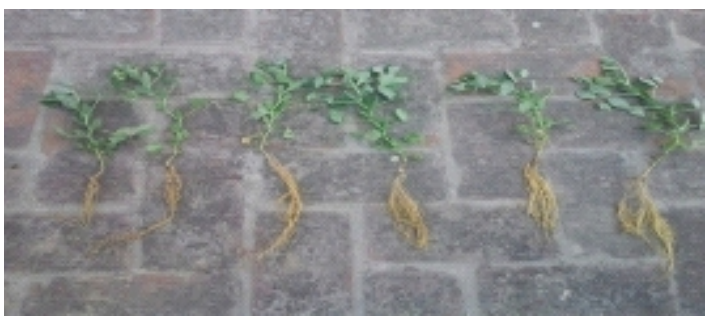

Fig.2: Pea plants with their roots after 45 days of $2 \mathrm{G}$ exposure lipid peroxidase and Guaiacol peroxidase. All the biochemical parameters increase with increase in time period both in Pea and Fenugreek.

\section{Nodule formation in the plants}

As the main feature of leguminous plants is the formation of legume, when the seedling grown in pots after 45 days there is formation of nodule in Pea and Fenugreek. The Rhizobium bacteria present in the soil is responsible for the formation of nodule in the plants. The main objective of present study is to study the effect of mobile phone radiation on the nodule formation in the leguminous plants. There is a variation in the nodule formation in Pea and Fenugreek seedling when compare wth the irradiated seedling.

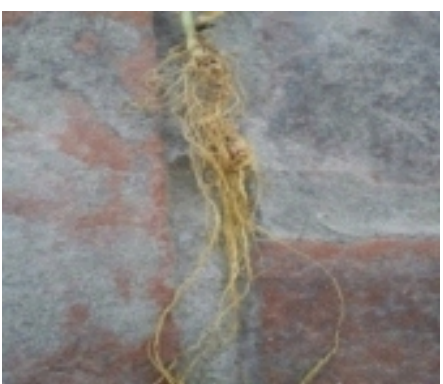

Control

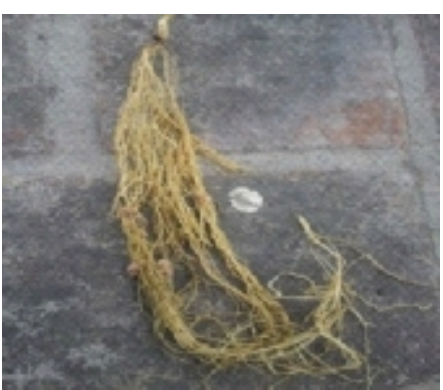

2 hour

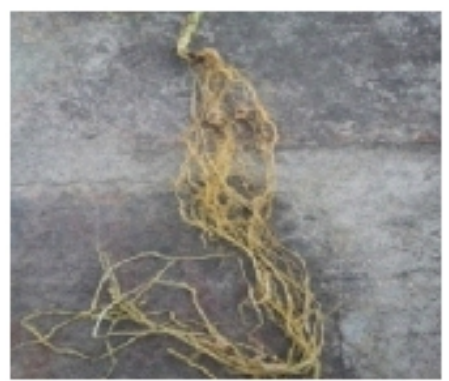

$1 / 2$ hour

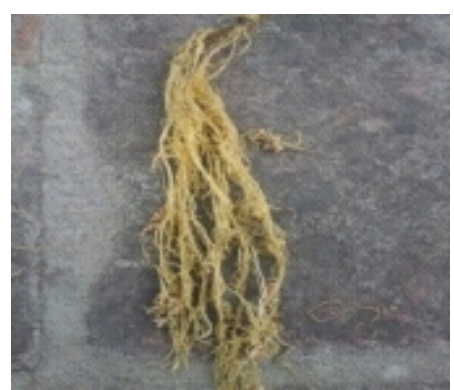

4 hour

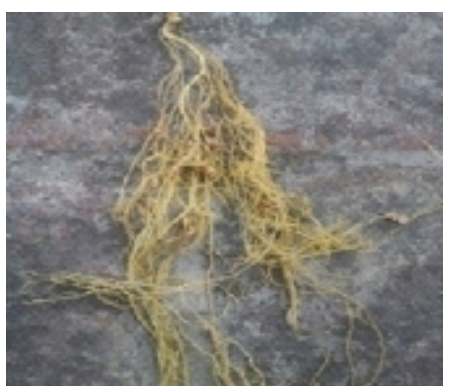

1 hour

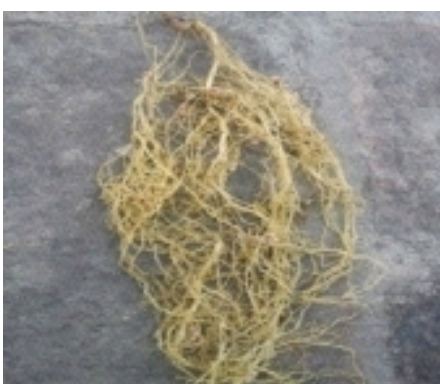

8 hour

Fig. 3: Pea roots with the nodule formation after 45 days of $2 G$ exposure Table 5: Standard error analysis of Pea seedling after radiation exposure (Biochemical)

\begin{tabular}{|c|c|c|c|c|c|c|c|}
\hline \multirow{2}{*}{$\begin{array}{l}\text { Time of } \\
\text { exposure }\end{array}$} & \multicolumn{3}{|c|}{ Protein estimation } & \multicolumn{2}{|c|}{ Lipid peroxidase } & \multicolumn{2}{|c|}{ Guaiacol peroxidase } \\
\hline & & $2 \mathrm{G}$ & $3 G$ & $2 \mathrm{G}$ & $3 G$ & $2 \mathrm{G}$ & $3 G$ \\
\hline Control & & $777 \pm 0.040$ & $0.789 \pm 0.05$ & $0.034 \pm 0.004$ & $0.032 \pm 0.010$ & $1.007 \pm 0.004$ & $1.082 \pm 0.011$ \\
\hline $1 / 2$ hour & & $794 \pm 0.047$ & $0.809 \pm 0.049$ & $0.036 \pm 0.025$ & $0.036 \pm 0.012$ & $1.013 \pm 0.006$ & $1.124 \pm 0.064$ \\
\hline 1 hour & & $347 \pm 0.037$ & $0.816 \pm 0.055$ & $0.053 \pm 0.026$ & $0.041 \pm 0.014$ & $1.023 \pm 0.012$ & $1.632 \pm 0.596$ \\
\hline 2 hour & & $378 \pm 0.082$ & $0.895 \pm 0.166$ & $0.058 \pm 0.027$ & $0.049 \pm 0.014$ & $1.027 \pm 0.012$ & $1.777 \pm 0.346$ \\
\hline 4 hour & & $385 \pm 0.007$ & $0.898 \pm 0.165$ & $0.037 \pm 0.014$ & $0.057 \pm 0.009$ & $1.032 \pm 0.017$ & $1.713 \pm 0.494$ \\
\hline 8 hour & & $390 \pm 0.085$ & $0.903 \pm 0.166$ & $0.063 \pm 0.024$ & $0.073 \pm 0.006$ & $1.039 \pm 0.013$ & $1.939 \pm 0.119$ \\
\hline
\end{tabular}


After the 45 days the diiferent changes has been observed in the plant root of Pea exposed with $2 \mathrm{G}$ mobile phone. The root length increases in irradiated seedling as compare to control. In control

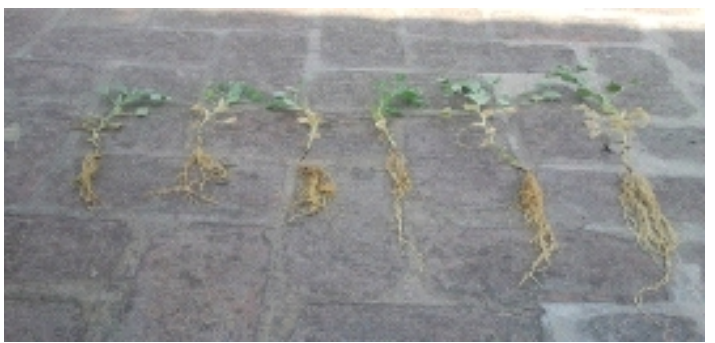

Fig. 4: Pea plants with their roots after 45 days of $3 G$ exposure the root length is $13 \mathrm{~cm}$, after $1 / 2$ hour exposure it is $20 \mathrm{~cm}$. With increase in time period of exposure there is an increase in the root length and in 8 hour the root length increase upto $23 \mathrm{~cm}$. Same results were obtained in case of $3 \mathrm{G}$ exposed seeds. After 45 days the observation show an increase in root length, number of nodule and diameter of nodule.

The Fenugreek seeds also exposed with $2 G$ and $3 G$ mobile phone radiation which result in an increase in the nodule formation with increased time period.

The root length with 8 hour time exposure increases as compare to control. The number of

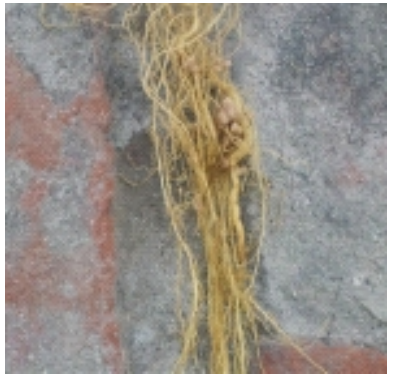

Control

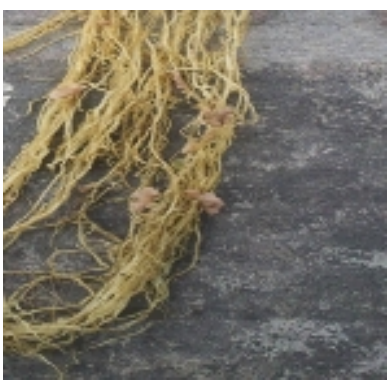

2 hour

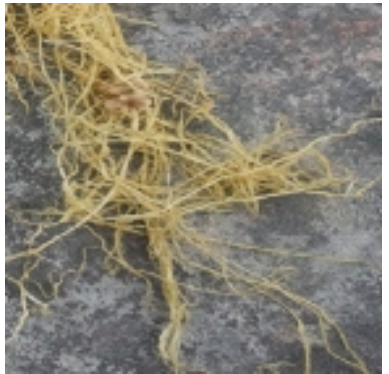

$1 / 2$ hour

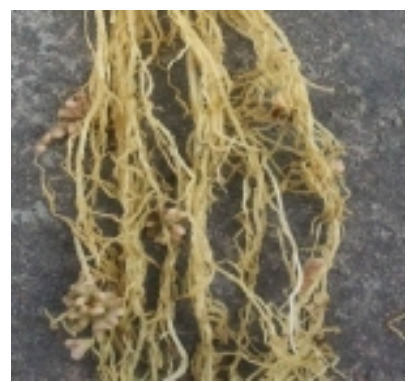

4 hour

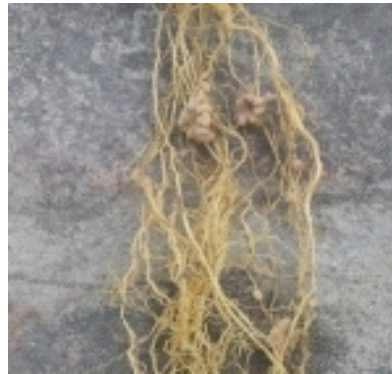

1 hour

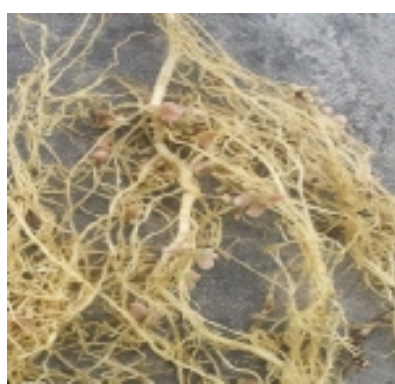

8 hour

Fig. 5: Pea roots with the nodule formation after 45 days of $3 \mathrm{G}$ exposure

Table 6: Standard error analysis of Fenugreek seedling after radiation exposure (Biochemical)

\begin{tabular}{|c|c|c|c|c|c|c|}
\hline \multirow{2}{*}{$\begin{array}{l}\text { Time of } \\
\text { exposure }\end{array}$} & \multicolumn{2}{|c|}{ Protein estimation } & \multicolumn{2}{|c|}{ Lipid peroxidase } & \multicolumn{2}{|c|}{ Guaiacol peroxidase } \\
\hline & $2 G$ & $3 G$ & $2 \mathrm{G}$ & $3 G$ & $2 \mathrm{G}$ & $3 G$ \\
\hline Control & $0.760 \pm 0.036$ & $0.811 \pm 0.003$ & $0.042 \pm 0.010$ & $0.002 \pm 0.001$ & $2.114 \pm 0.007$ & $2.340 \pm 0.141$ \\
\hline $1 / 2$ hour & $0.767 \pm 0.036$ & $0.829 \pm 0.022$ & $0.046 \pm 0.007$ & $0.008 \pm 0.001$ & $2.119 \pm 0.006$ & $2.330 \pm 0.286$ \\
\hline 1 hour & $0.771 \pm 0.035$ & $0.842 \pm 0.028$ & $0.049 \pm 0.010$ & $0.015 \pm 0.002$ & $2.128 \pm 0.009$ & $2.241 \pm 0.242$ \\
\hline 2 hour & $0.773 \pm 0.033$ & $0.847 \pm 0.027$ & $0.056 \pm 0.010$ & $0.018 \pm 0.001$ & $2.131 \pm 0.008$ & $2.320 \pm 0.262$ \\
\hline 4 hour & $0.775 \pm 0.035$ & $0.857 \pm 0.028$ & $0.059 \pm 0.010$ & $0.019 \pm 0.001$ & $2.135 \pm 0.0060$ & $2.437 \pm 0.064$ \\
\hline 8 hour & $0.777 \pm 0.036$ & $0.865 \pm 0.025$ & $0.067 \pm 0.12$ & $0.022 \pm 0.001$ & $2.140 \pm 0.008$ & $2.435 \pm 0.158$ \\
\hline
\end{tabular}


nodule and their size also show an increase with increased time period. In control the number of nodules was 9 and after 8 hour exposure it was 15 nodules.

\section{DISCUSSION}

The present study was conducted to explore the effect of microwave radiation emitted from mobile phone on germination percentage, seedling length, fresh weight, dry weight along with all biochemical parameters. The study concluded that the mobile phone radiations cause change in morphology and biochemistry of the plants. The previous research shows that there was reduction in germination percentage, seed length, fresh weight and dry weight of mobile phone irradiated seeds with different wave length (Afzal and Mansoor 2012) and in present study the increase in seed length, decrease in fresh weight and increase in dry weight has been reported. The author reported that the mobile phone radiations significantly reduced the seedling length and dry weight of seeds after exposure for $0.5,1,2$, and $4 \mathrm{~h}$. Decrease in trend was observed for seed germination, seedling vigour, plant height, root length and biomass $\%$ for most of the samples used with increase in microwave power and exposure time as compared to control (Ragha et al. 2011). Irradiation provoked insignificant changes in lipid peroxidation and soluble protein content, while protein oxidation intensity was significantly decreased when dose of

Table 7: Morphological analysis of Pea after 2G mobile phone radiation exposure (In vivo)

\begin{tabular}{lcccccc}
\hline & control & $\mathbf{1} / \mathbf{2}$ hour & $\mathbf{1}$ hour & $\mathbf{2}$ hour & $\mathbf{4}$ hour & $\mathbf{8}$ hour \\
\hline Root length $(\mathrm{cm})$ & 13 & 20 & 20.5 & 20.5 & 21 & 23 \\
Number of nodule & 14 & 15 & 21 & 22 & 23 & 27 \\
Average size of nodule $(\mathrm{mm})$ & 4 & 5 & 5 & 6 & 7 & 9 \\
\hline
\end{tabular}

$\mathrm{cm}$-centimeter, mm- millimeter

Table 8: Morphological analysis of Pea after 3G mobile phone radiation exposure (In vivo)

\begin{tabular}{lcccccc}
\hline & control & $\mathbf{1}$ 2 hour & $\mathbf{1}$ hour & 2 hour & $\mathbf{4}$ hour & $\mathbf{8}$ hour \\
\hline Root length $(\mathrm{cm})$ & 11 & 21 & 21 & 22 & 23 & 24 \\
Number of nodule & 15 & 17 & 21 & 22 & 24 & 27 \\
Average size of nodule $(\mathrm{mm})$ & 5 & 6 & 7 & 8 & 8 & 9 \\
\hline
\end{tabular}

$\mathrm{cm}$-centimeter, mm- millimeter

Table 9:Morphological analysis of Fenugreek after 2G mobile phone radiation exposure (In vivo)

\begin{tabular}{lcccccc} 
& control & $\mathbf{1} / \mathbf{2}$ hour & $\mathbf{1}$ hour & 2 hour & $\mathbf{4}$ hour & $\mathbf{8}$ hour \\
\hline Root length (cm) & 6.5 & 7 & 7.6 & 8 & 9 & 10 \\
Number of nodule & 9 & 10 & 10 & 12 & 12 & 15 \\
Average size of nodule (mm) & 1 & 2 & 3 & 4 & 5 & 5 \\
\hline Table 10: Morphological analysis of Fenugreek after 3G mobile phone radiation exposure (In vivo) \\
\hline
\end{tabular}


10 kGy was applied. Presented results implicated that increased antioxidant capacity and protein stability of were increased after application of irradiation (Abd 2011).

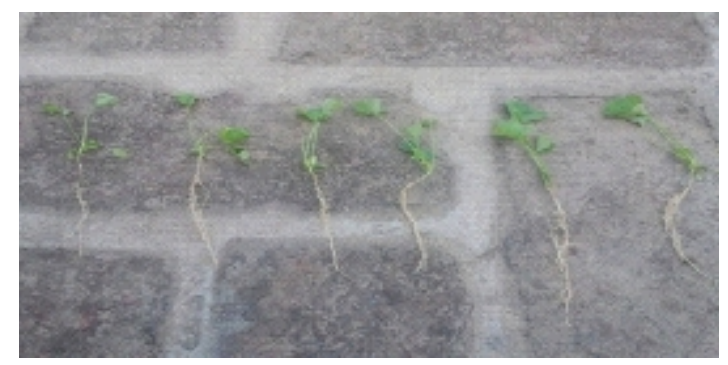

Fig. 6: Fenugreek plants with their roots after 45 days of $2 \mathrm{G}$ exposure
In present study, there was an increase in enzyme activity such as lipid peroxidase and Guaiacol peroxidase both in Pea (Pisum sativum) and Fenugreek (Trigonella foenumgraecum) as the radiation exposure increase, similar results were shown by (Kouzmanova et al. 2009). In Pea the lipid peroxidation increases from 0.034 to 0.063 when exposed with the $2 \mathrm{G}$ mobile phone radiation. In $3 G$ exposed seeds of Pea the lipid content increases from 0.032 to 0.073 .

Similarly these finding were in agreement with (Singh and Prakash 2011). The protein content also increased with increase in radiation exposure. After maximum radiation exposure the protein content increases as 0.890 for $2 \mathrm{G}$ and 0.903 for

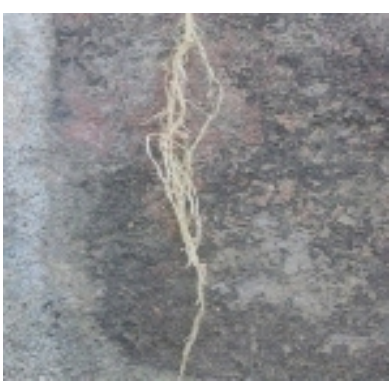

Control

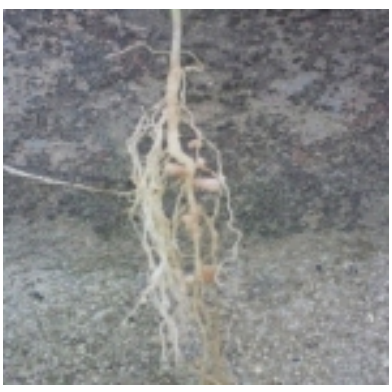

2 hour

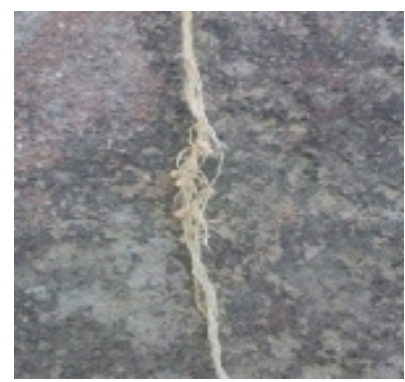

$1 / 2$ hour

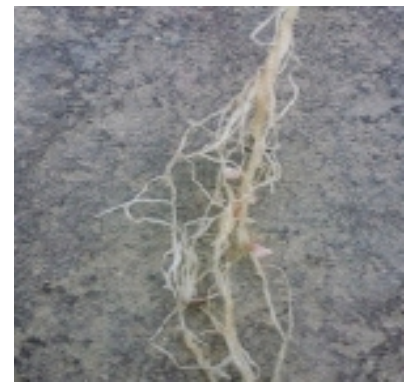

4 hour

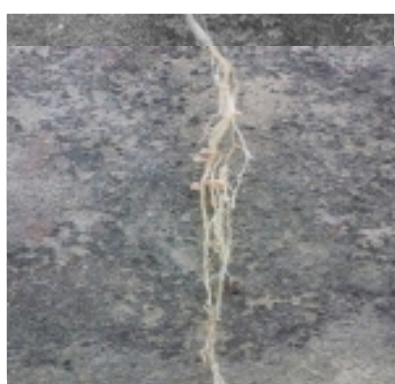

1 hour

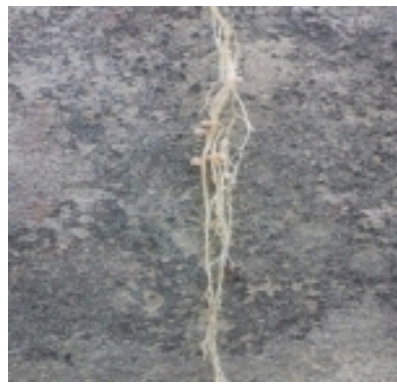

8 hour

Fig. 7: Fenugreek roots with the nodule formation after 45 days of $2 \mathrm{G}$ exposure

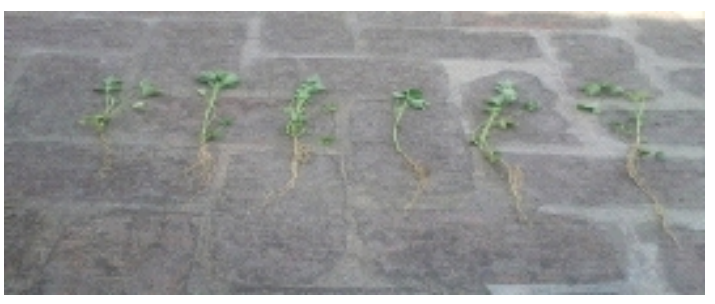

Fig. 8: Fenugreek plants with their roots after 45 days of $3 G$ exposure
3G. Guaiacol peroxidase enzyme activity for 8 hours was 1.039 for $2 G$ and 1.939 for $3 G$. Same increase activity was observed in Fenugreek. This increase in enzyme activity shows the protection against the mobile phone radiation. As the main objective was to study the effect of mobile phone radiation on the nodule formation in leguminous plants, the radiation exposure also showed an increase in nodule formation in the leguminous plants. In Pea after 


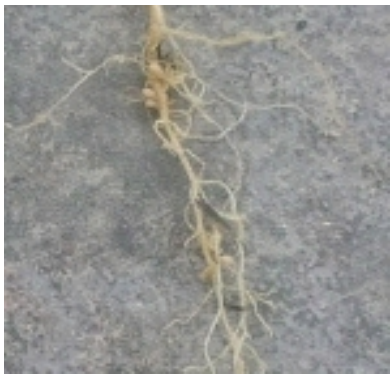

Control

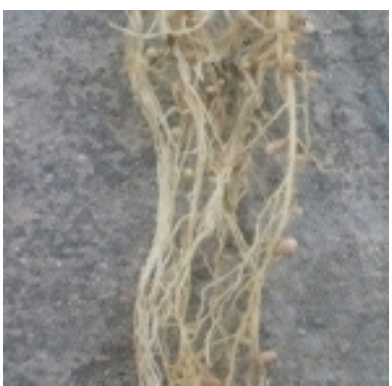

2 hour

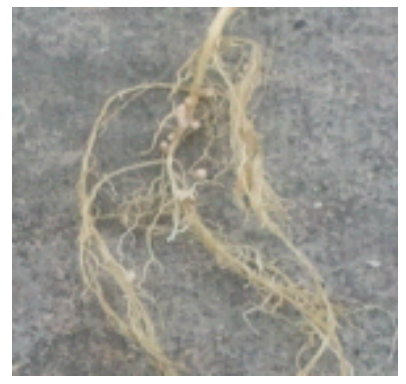

$1 / 2$ hour

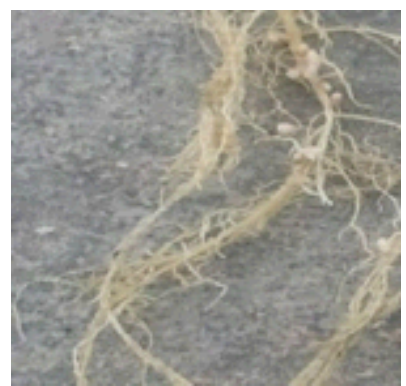

4 hour

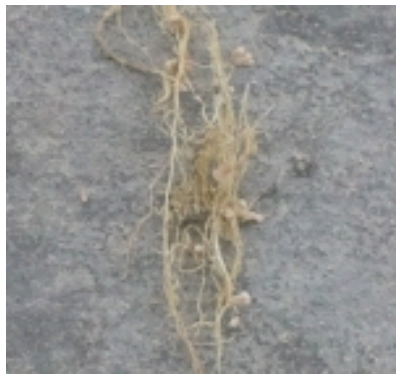

1 hour

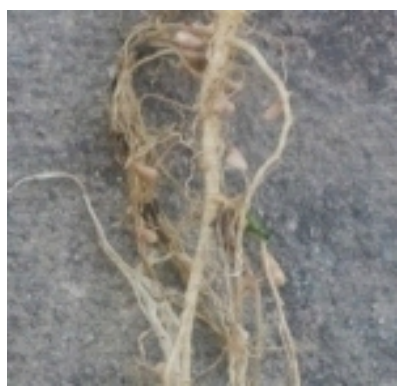

8 hour

Fig. 9: Fenugreek roots with the nodule formation after 45 days of $3 G$ exposure

maximum radiation exposure with $2 \mathrm{G}$ mobile phone the root length, nodule number and size increase as $23 \mathrm{~cm}, 27$ and $9 \mathrm{~mm}$. After $3 \mathrm{G}$ mobile phone radiation exposure it increases as $24 \mathrm{~cm}, 27$ and $9 \mathrm{~mm}$. In case of Fenugreek root length, nodule number and size increase as $10 \mathrm{~cm}, 15$ and $5 \mathrm{~mm}$ for $2 \mathrm{G}$ and $12 \mathrm{~cm}, 15$ and $6 \mathrm{~mm}$ for $3 \mathrm{G}$. The 8 hour radiation exposure showed the maximum nodule formation with increase in diameter and root length. So in this study the effect of microwave radiation emitted from mobile phone were investigated which show a considerable increase in the plant growth. The results indicate that all these effects should be further evaluated and investigated for plant growth.

\section{REFERENCES}

1. Abd El-M, Afify MR, Mohamed MR, Ebtesan AM, Hossam S El-B. Effect of Gamma Radiation on Protein Profile, Protein Fraction and Solubility's of Three Oil Seeds: Soybean, Peanut and Sesame. Not Bot Horti Agrobo 39: 90-98 (2011).

2. Afzal M, Mansoor S. Effect of mobile phone radiations on morphological and biochemical parameter. Asian Journal of Agricultural Science 4: 149-152(2012).

3. Akhyal A, Yasar K, Ahmet S, Balik DT, Balik $\mathrm{HH}$. Effect of Electromagnetic Waves Emitted by Mobile Phone Radiations on Germination, Root Growth and root tip cell Mitotic Division of Lens culinaris. Pol J Environ. Stud 21: 23- 29 (2010).
4. Aladjadjian A. Effect of microwave radiation on seeds of Lentils (Lens culinaris). Romanian j. Biophys 20: 213-221(2010).

5. Ashiho LS. Mobile technology: Evolution from $1 G$ to $4 G$. Electronics for you (2003).

6. Beltagi HS, Osama KA, WaelEI-D. Effect of low doses $g$-irradiation on oxidative stress and secondary metabolites production of rosemary (Rosmarinus officinalis) callus culture Radiation. Phy and Chem 80: 968976 (2011).

7. Beijerinck MW. Die Bacterien der Papilionaceenknollchen. Botanische Zeitung 46: 725-804 (1888).

8. Byun MW, Kang IJ. Effect of ã-Irradiation on Soya Bean proteins. J Science Food 
Agriculture 66: 55-60 (1994).

9. Crowe M, Tavilla E. Mobile phone technology smarter than we thought. Federal Reserve Bank of Boston 136-149 (2012).

10. Dubravka S, Mirjana M, Boris MP. Irradiation Effects on Phenol Content, Lipid and Protein Oxidation and Scavenger Ability of Soybean Seeds. International Journal of Molecular Science 8: 618-627 (2007).

11. Dhindsa RS, Dhindsa PP, Thrope TT . Leaf senescence: Correlated with increased level of membrane permeability and lipid per oxidation and levels of super oxide dismutase and Catalase. J Exp Bot 32: 93101(1981).

12. Foster KR, Repacholi, Michael H .Biological Effects of Radiofrequency Fields: Does Modulation Matter. Radiation Research 162: 219-225 (2004).

13. Fredan A, Mohammed AA. Nitrogen Fixing Legumes in the Plant Communities. American Journal of Environmental Sciences 7: 166-172 (2011).

14. Heath KD, Tiffin P. Stabilizing mechanisms in legume Rhizobium mutualism. Evolution 63: 652-662(2009).

15. lancu CV, Wright ER, Heymann JB, Jensen GJ. A comparison of liquid nitrogen and liquid helium as cryogens for electron cryotomography. Journal of Structural Biology 153: 231-240(2006).

16. Indge B. The Nitrogen Cycle. Biological Sciences Review 13: 25-27(2000).

17. Jakubowski T. The impact of microwave radiation at different frequencies on weight of seed potato germs and crop of potato tuber. Agricultural engineering 6: 57-64(2010).

18. Khalafallah AA, Sallam SM. Response of Maize seedling to microwave at $945 \mathrm{MHz}$. Romanian J Biophys, 19: 49-62 (2009).

19. Kouzmanova M, Dimitrova M, Dragolova D, Atanasova GA. Alternation in enzyme activities in leaves after exposure of Plectranthus $s p$. Plants to $900 \mathrm{MHz}$ electromagnetic field. Biotechnol \& Biotechnol EQ: 611-615(2009).

20. Krishnan R, Murugan K. Effect of Mobile Phone Radiation on Antioxidant Machinery in Roots of Onion (Allium cepa). Asian J. Exp. Biol.Sci. 2: 667-672(2011).
21. Kumar G. Cell Tower Radiation. Electrical Engineering Department IIT Bombay, Powai, Mumbai 3-32(2010).

22. Kwan HN. Non-lonizing Radiations-Sources, Biological Effects, Emissions and Exposures. Proceedings of the International Conference on Non-lonizing Radiation at UNITEN ICNIR2003 Electromagnetic Fields and Human Health. 44: 50-57 (2003).

23. Lowry, OH, NJ Rosbrough, AL Farr, and RJ Randall. J. Biol. Chem. 193: 265 (1951).

24. Lavoisier AL. Elements of chemistry in a new systematic order containing all the modern discoveries. Courier Dover Publications 15 ISBN0-486-64624-6 (2000).

25. Liener IE. Nutritional Value of Food Protein Products" In Smith and Circle, editors; Soybeans: Chemistry and Technology. The AVI Publishing Co Westport Connecticut 113: 1034-44 (1992).

26. Lindemann WC, Nitrogen fixation by legume NMSU and the U.S. Department of Agriculture. Cooperating Guide A-129 (2003).

27. Maity JP, Chakraborty S, Kar S, Panja S, Jean J, Samal AC, Chakraborty A, Santra SC. Effects of gamma irradiation on edible seed protein, amino acids and genomic DNA during sterilization. Food Chem 114: 1237 1244 (2009).

28. Nisizawa M. Radiation induced sol-gel transition of protein: effect of radiation on amino-acid composition and viscosity. J Appl Polym Sci 36: 979-981 (1988).

29. Pavadai P, Girija M, Dhanavel D. Effect of Gamma Rays on some Yield Parameters and Protein Content of Soybean in M2, M3 and M4 Generation. Journal of Experimental Sciences 1: 08-11(2010).

30. Rhaga L, Mishra S, Ramachandran V. Effect of low power microwave fields on seeds germination and growth rate. Journal of electromagnetic Analysis and application 3: 165-171 (2011).

31. Ruediger HW. Genotoxic effects of radiofrequency electromagnetic fields. Pathophysiology (Elsevier) 16: 67-69 (2009).

32. Schuz J, Jacobsen R, Olsen JH, Boice JD, McLaughlin JK, Johansen C. Cellular 
Telephone Use and Cancer Risk: Update of a Nationwide Danish Cohort. Journal of the National Cancer Institute 98: 1707-1713 (2006).

33. Sharma VP, Singh HP, Kohli RK, Batish DR. Mobile phone radiation inhibits Vigna radiata (mung bean) root growth by inducing oxidative stress. Sci Total Environment 21:5543-5547 (2009).

34. Singh HP, Prakash SV. Electromagnetic radiations from cell phone inhibit plant root growth through induction of oxidative damage chemicals and environmental. Health Issues 22: 249-252 (2011).

35. Smith AK, Circle SJ. Soybeans: Chemistry and Technology. AVI publishing 76: 242-245 (1972).

36. Smith C, Collins D. 3G Wireless Networks, 136: (2000).

37. Yue J, Zou J. Study of radiation effect on Cotton (Gossypium hirsutum). Journal of Agricultural Science 7: 85-94 (2012) . 